\title{
Incidence of Corrosion on Electric Power Losses in ACSR Cables
}

\author{
Incidencia de la corrosión en las pérdidas de energía eléctrica en cables ACSR
}

\author{
Carlos G. Cárdenas ${ }^{1 *}$, Oscar M. Pardo ${ }^{1}$, Edward Barajas ${ }^{1}$ y Alfonso Santos ${ }^{2}$ \\ ${ }^{1}$ Ingeniería Electromecánica, Universidad Antonio Nariño, Bucaramanga, Colombia \\ ${ }^{2}$ Ingeniería Electromecánica, Universidad Pontificia Bolivariana, Bucaramanga, Colombia
}

\begin{abstract}
This research performed a marine atmosphere simulation, using a saline fog chamber as a means to generate accelerated corrosion of conducting aluminum with steel reinforcement, used to construct electric power transport networks. The rate of corrosion was determined through the gravimetric method that consisted in measuring the loss of mass taking place in the sample. The experiment was conducted by taking three samples of ACSR (Aluminum with Steel Reinforcement) cable of different gauges, which received a flow of alternate current while the metal was being corroded. Through measuring equipment, electric power consumption was recorded to verify changes in the energy transported, given the exposure of the samples to corrosion. Likewise, voltage and current were measured to determine the system's stability. Results showed that the hours of exposure of the samples in the saline fog chamber generated greater effects in galvanized steel, causing damage to its zinc layer, in contrast to aluminum that turned out to be more resistant to this type of contaminant. Also, the electric power losses registered were not significant; possibly due to the sample's exposure and energizing times.
\end{abstract}

Keywords: Aluminum Conductor with Steel Reinforcement, Saline Fog Chamber, Electric Power Losses, Incidence of Corrosion

\section{Resumen}

En la presente investigación se realizó una simulación de atmosfera marina, utilizando la cámara de niebla salina como medio para generar la corrosión acelerada del conductor de Aluminio con refuerzo de acero, el cual es utilizado en la construcción de redes de transporte de energía eléctrica. La velocidad de corrosión se determinó por el método de gravimetría que consistió en la medición de la pérdida de masa que presentó la probeta. El experimento se hizo tomando tres probetas de cable ACSR de diferente calibre, al cual se le aplicó un flujo de corriente alterna mientras se corroía el metal. Mediante un equipo de medida se registró el consumo de energía eléctrica para verificar la presencia de cambios en la energía transportada, debido a la exposición de las muestras a la corrosión. De igual manera la tensión y la corriente se midieron para determinar la estabilidad del sistema. El resultado mostró que las horas de exposición de las probetas en la cámara de niebla salina generaron mayor afectación en el acero galvanizado causando daño en su capa de zinc, al contrario del aluminio que mostró ser más resistente a este tipo de contaminante. Así mismo las pérdidas de energía eléctrica registradas no fueron significativas debido posiblemente al tiempo de energización y de exposición de las probetas.

Palabras clave: Conductor De Aluminio Con Refuerzo De Acero, Cámara De Niebla Salina, Pérdidas De Energía Eléctrica, Incidencia De La Corrosión

*Corresponding Author.

E-mail: carloscarde@uan.edu.co
How to cite: Cárdenas, C.et al., Incidence of Corrosion on Electric Power Losses in ACSR Cables, TECCIENCIA, Vol. 11 No. 20., 2733, 2016, DOI: http:/dx.doi.org/ 


\section{Introduction}

In electric power distribution network systems in the Colombian Atlantic coast we can find medium voltage (MV) lines of 13,200 and 34,500 Volts (V). These networks are currently constructed with aluminum (Al) [1] [4] wires with a steel core (ACSR) ) [2] [5] [7]. Although in the past cables were made out of copper $(\mathrm{Cu})$, these are no longer used due to their high costs and repeated theft.

Corrosion, a natural phenomenon and the main cause of metal deterioration [11] [15], occurs due to chemical or electrochemical reactions between an electrolytic environment and the material exposed to this environment or the electrical contact between two metal, one more noble than the other.

Colombia's Atlantic zone has problems with its electric networks; in part because it is quite close to the sea and because of high temperatures and relative humidity [2] [7], making them vulnerable to chemical attack due to the mixture of salt and water and/or the reaction of carbon dioxide with water [17] [18].

Companies dedicated to electric power transmission and distribution [19] [24], offering their services in Colombia's Atlantic zone, have shown greater interest in the corrosive effects on their ironwork and structures, given that saltpeter deteriorates metals until their rupture, causing surges and interruptions in the power distribution lines [25] [28].

The aim of this research was to learn of the incidence of corrosion upon electric power losses to study its behavior in saline environments. Thus, ACSR is the conductor studied herein (given that it is the one currently used), through a test bench that simulates an electric network exposed to a normal environment and to a saline environment to obtain results that help to delve into studying the phenomenon described and contributing in the search for solutions to problems caused by electric power losses.

\section{Methods}

The tests were conducted in two stages:

The first consisted in subjecting the three ACSR conductors composed by aluminum wires $(1350 \mathrm{H} 19)$, with steel core covered by galvanized zinc, gauges No. 4, 2, and 1/0, lengths of 158,112 , and $83 \mathrm{~cm}$, respectively, connected to a threephase busbar $(240 \mathrm{~V} / 120 \mathrm{~V})$ of the protection panel of the Corporation for Corrosion Research (CIC, for the term in Spanish), whose electric power supply comes from the Piedecuesta municipal grid. Thereafter, the electric power consumption was measured at the source input and on the installed load, requiring a test bench - as security against electrical risk - for electrical connections where protection and measurement equipment are installed. Afterward, electric measurement instruments were implemented to check on the behavior of currents, voltage, and energy consumption.

It should be mentioned that the first stage is provided as control and reference test to compare the variables presented after the application of accelerated corrosion of the cables. The second phase replicated the previous procedure, adding the saline fog chamber (SFC) intervention to which a saline solution was poured composed of five parts of sodium chloride $(\mathrm{NaCl})$ and 95 parts of type IV demineralized water and prepared according to ASTM B117 standard (chapter 8 - saline solution), under CIC supervision.

The samples (bare ACSR cable) were connected to each other, according to gauges via aluminum-aluminum connector and their loads with bimetallic connectors to permit closing the circuit and accomplishing the reading of parameters like amperage, voltage, and energy. The gauges of the samples exposed were number 4,2, and 1/0; these were placed on plastic supports and separated to avoid short circuit and subjected during $337.5 \mathrm{~h}$ to the simulation of saline atmosphere and with drying times to accelerate the corrosion effects; during this period, the ACSR cable was energized and energy consumption was recorded in kilo watt-hour (kWh).

\section{Results and Analysis}

With SFC, uniform corrosion was reproduced, associated to a marine atmosphere in which corrosion factors, like temperatures of $35^{\circ}$, relative humidity at $100 \%$, saline fog, and alternate humidification and drying cycles.

Also, considering the material with which the conductors are composed, it is pertinent to state that it is common for aluminum to present localized (pit type) and galvanic corrosion due to contact between aluminum and galvanized steel.

The marine-type atmospheric conditions reproduced by the SFC is charged with corrosive contaminating agents, like sodium chloride $(\mathrm{NaCl})$; however, due to the SFC characteristics, it was not possible to replicate dust as another one of the contaminants that are part of a marine atmosphere. The spray pressure of the saline solution in mist form was of 12 psi.

\subsection{Analysis of the corrosion tests process}

Exposure of the cables in the saline fog chamber began on 26 March 2014 at 7:00 a.m. and culminated on 09 April 2014 


\section{TECCIENCIA}

at 8:30 a.m. The samples were exposed for a total of 337.5

hours (14 days $+1.5 \mathrm{~h})$.

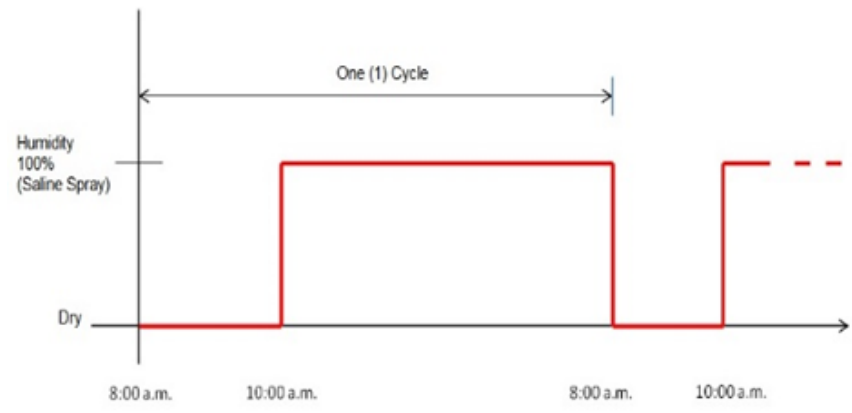

Figure 1 Exposure cycles.

of corrosion was $0.403700293 \mathrm{MPa} . \mathrm{A}=265.2262063 \mathrm{~cm}^{2}$,

During the $337.5 \mathrm{~h}$ of operation, the chamber maintained a constant cycle in which it had two hours of drying from 8:00 to 10:00 a.m. and the saline spray from 10:00 a.m. to 8:00 a.m. of the following day (Fig. 1). These two hours of drying were carried out to diminish the permanence of the humidity film on the metallic surface and, thus, increase the rate of corrosion.

Figures 2 and 3 show, on the metallic surface of the samples, the layers of contaminants; in this case, $\mathrm{NaCl}$ residues and the presence of corrosion.

Upon terminating the exposure period, the specimen was dismounted from each of the gauges exposed and then, through scaling the corrosion products were eliminated. By taking the Standard Practice for Preparing, Cleaning, and Evaluating Corrosion Test Specimens (ASTM G1 standard), the mean rate of corrosion was obtained with the following equation:

$R=\frac{K * W}{A * T * D}$

Where:

$\mathrm{K}$ : is a constant $8.76 \mathrm{e} 04$ (this value of the constant is used to have the results in millimeters per year ( $\mathrm{mm} / \mathrm{p} . \mathrm{a}$.)).

$\mathrm{W}$ : mass loss in grams

A: area in $\mathrm{cm}^{2}$

$\mathrm{T}$ : time of exposure in hours

D: density in $\mathrm{g} / \mathrm{cm}^{\wedge} 3$ (see appendix X1 ASTM G1).

The area of the \#4 ACSR was $316.3279 \mathrm{~cm}^{2}$; its initial mass was $97.1934 \mathrm{~g}$, and the final mass after scaling was $96.06 \mathrm{~g}$; lastly, density was at $2.705 \mathrm{~g} / \mathrm{cm}^{3}$. The mean rate of corrosion was 0.343802207 millimeters per year.

The gauge \#2 ACSR showed an area of $282.8465959 \mathrm{~cm}^{2}$, initial mass of $159.99 \mathrm{~g}$, and final mass of $158.8 \mathrm{~g}$. The rate initial mass of $179.3887 \mathrm{~g}$, final mass of $179.69 \mathrm{~g}$, and for

the \#1/0 gauge the rate of corrosion was $0.976340343 \mathrm{MPa}$ (Fig. 4). Small pits on the aluminum and degradation of the zinc film on the steel were observed via BX46 optical microscope (Figs. 5, 6, 7, and 8).

\subsection{Analysis of the energizing test process}

Within the use of the correlation, the criteria shown in Table 1 were selected to determine if the test was satisfactory. This was done to verify a linear association between two variables.

The relationship of voltage with respect to current during the tests conducted with load could be observed; by correlating these two factors, an average correlation of 0.99 $(0.997585893)$ and a standard deviation of 0.002 (0.002122663) was obtained, indicating that the test complies with the relationships that can be attributed to the electric variables in question. When comparing between input and output voltage for each phase, the results presented in Fig. 9 were obtained.

According to Table 7, an excellent degree of agreement exists among the voltages registered for each of the three phases, which ranged from a correlation coefficient of 0.998 to 1 .

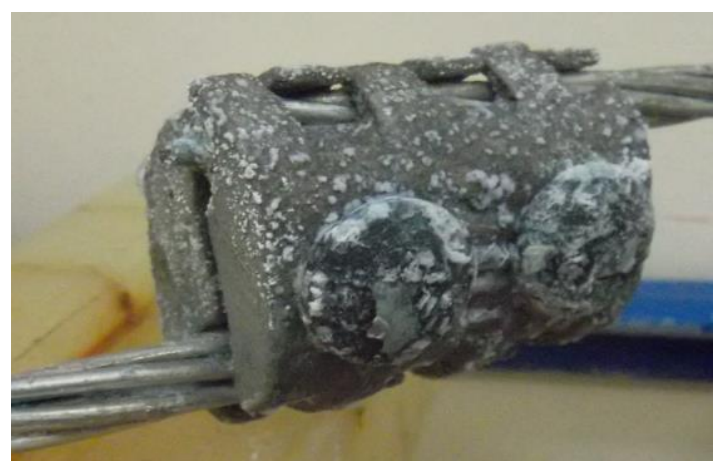




\section{TECCIENCIA}

Figure 2 Specimen after $337.5 \mathrm{~h}$ of exposure to the saline fog.

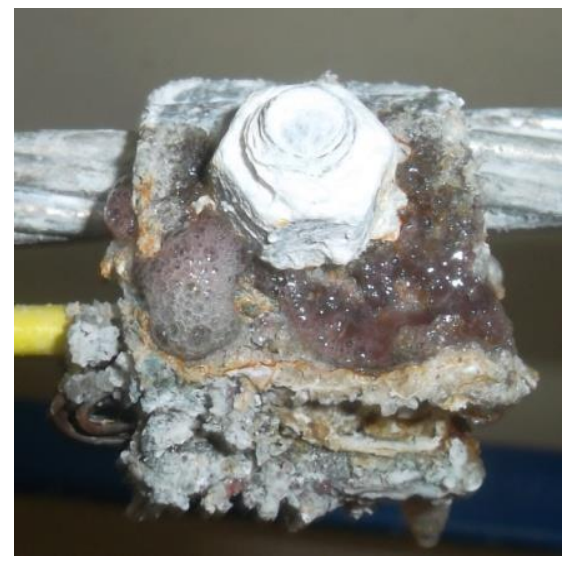

Figure 3 Samples after $337.5 \mathrm{~h}$ of exposure to saline fog.

It is important to indicate that for day 02 April, the measurements evidenced a registry of the three phases, which were close to coinciding: $\mathrm{Va} 0.9998, \mathrm{Vb} 0.9997$, and Vc 0.9997.

This event may be explained because: for the date the measurement was registered no voltage fluctuation was noted; also, the loads applied to the three phases were basically resistive elements. Consequently, no difference was observed between input and output voltage, which guaranteed the stability of the test in question on voltage registry and control. Similarly, it was established that the only variable in the system is associated to electric power consumption and the variables inherent to the behavior of the electric elements.

Likewise, the input and output currents were measured and compared (Fig. 10) to minimize the variables that can affect the analysis of the test results. Until now, the tests agree with the expectations, but the input voltage is not equal to the output voltage, as with the current. Even so, a variable can explain what occurs in the system, the input voltage, and the output voltage. For this purpose, we take the actual voltage value recorded for the three phases at the input and output; the input voltage corresponds to the voltage provided by the grid, and the output voltage is that delivered to the load (Fig. 11).

To assess the evolution of conductors within the system, voltage, current, and power values are taken during several days of the test around one hour of continuous charge. This difference of the power value presented in a power average for each day, as well as a standard deviation of the results, is shown in Fig. 12, evidencing an average loss in the system.
It may be stated that the resistance in the system is determined by the division between the system's voltage and current (Fig. 13).

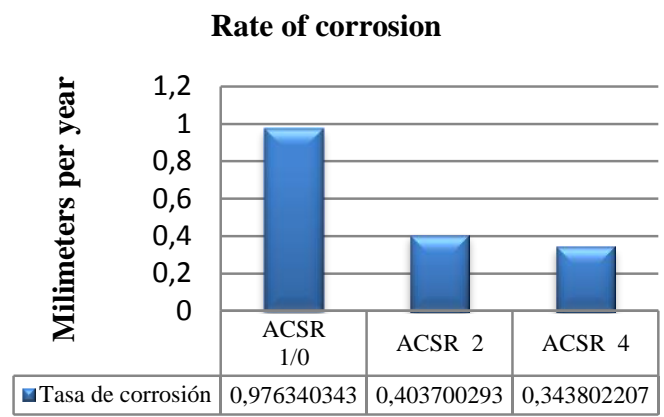

Figure 4 Average rate of corrosion

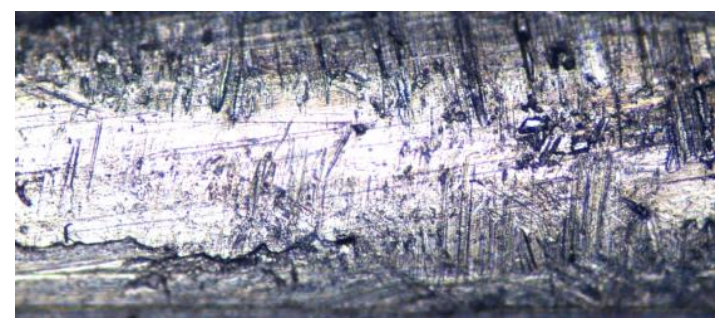

Figure 5. Aluminum before entering the SFC

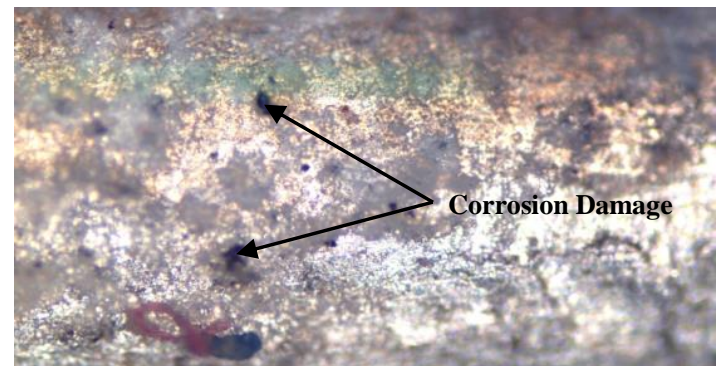

Figure 6. Aluminum after exiting the SFC

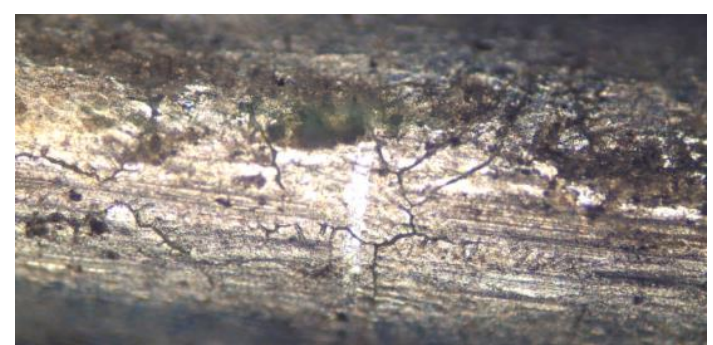

Figure 7. Steel core before exposure to the saline fog 


\section{TECCIENCLA}

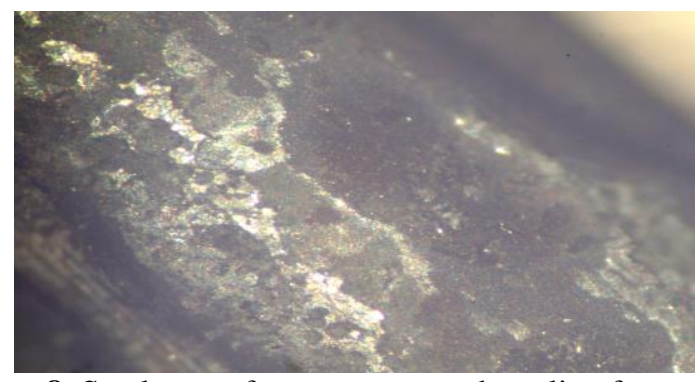

Figure 8. Steel core after exposure to the saline fog

\begin{tabular}{|c|c|}
\hline $\begin{array}{c}\text { Correlation } \\
\text { coefficient }\end{array}$ & Degree of agreement \\
\hline 0 & Null \\
\hline$<0.40$ & No agreement \\
\hline $0.40-0.60$ & Moderate agreement \\
\hline $0.60-0.75$ & Regular agreement \\
\hline $0.75-0.85$ & Good agreement \\
\hline $0.85-1$ & Excellent agreement \\
\hline
\end{tabular}

Table 1 Degree of agreement for the correlation in the test

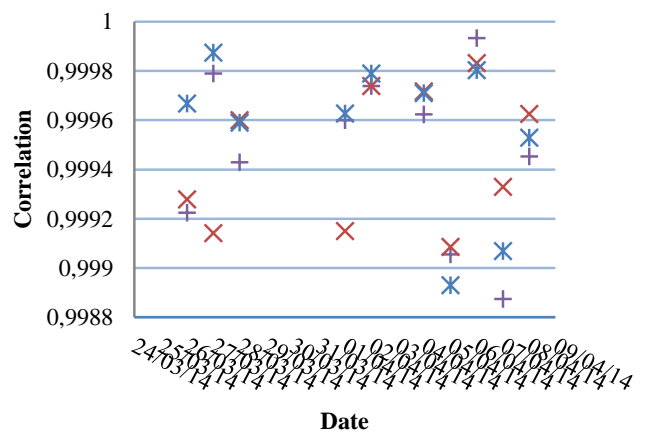

$+\mathrm{Vb}$

$\times \mathrm{Vc}$

* Va

Figure 9 Input vs. output voltage correlation

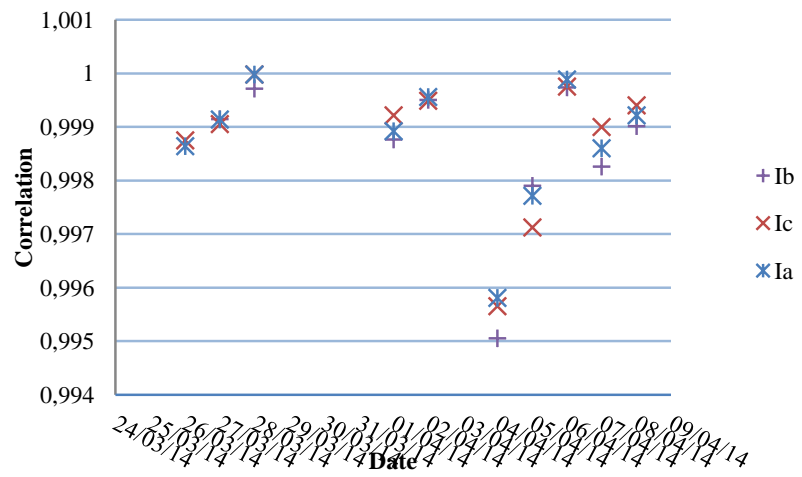

Figure 10 Input vs. output current correlation
Given the continuity of the test, during days $07 / 04 / 2014$ and 08/04/2014 the slope is calculated during one hour every 5 min to contemplate the evolution of the slope and the cut-off point during these two days. The equation of resistance in the system, where " $r$ " represents the system's resistance "per unit", $\left(\mathrm{R}_{\text {sist }}\right)$ is the constant resistance value that represents the system, and "mr" represents the slope that controls the system's total resistance variation over time:

$r=R_{\text {sist }}+m r * t$

By analyzing the data "per unit", the evolution of slope (mr), which is calculated with Equation 3 and its tendency over time, evidenced in Figures 14, 15, and 16 with domain from 0 to 1800 every $5 \mathrm{~min}$, would yield an estimate of the affectation of the material as time passes.

$b=\frac{\sum(x-\bar{x})(y-\bar{y})}{\sum(x-\bar{x})^{2}}$

\section{Conclusions}

The samples, after having been subjected to corrosion during the $337.5 \mathrm{~h}$, did not show major surface damage, according to that registered through the Olympus BX46 microscope. This could be attributed to the alumina layer generated when aluminum comes in contact with an oxidizing medium, like oxygen and water. It is worth mentioning that galvanized steel, which is part of the ACSR, did show important surface deterioration because the zinc layer used as corrosion protector was affected. Without this zinc layer and with more hours of exposure to the saline fog, it is likely that due to the effect of the galvanic couple between the aluminum and the steel, the steel corrodes at a higher rate.

The input and output voltage, as well as the input and output current, had excellent correlation; this means that although the values were not equal, their deviations were not sufficiently significant to alter the tests.

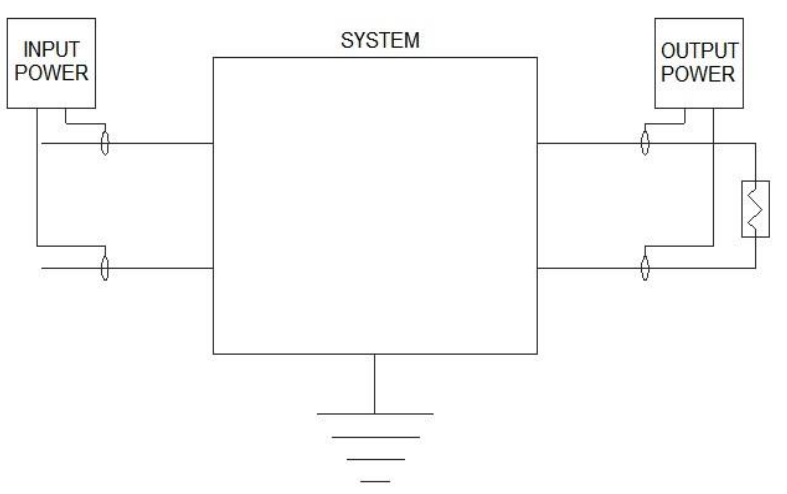

Figure 11 Power distribution 


\section{TECCIENCIA}

Regarding the general aim of this work, no clear evidence indicates that, in this test, corrosion affects electric power losses, probably due to the time the specimen was energized in non-continuous manner during the two weeks the samples were exposed.

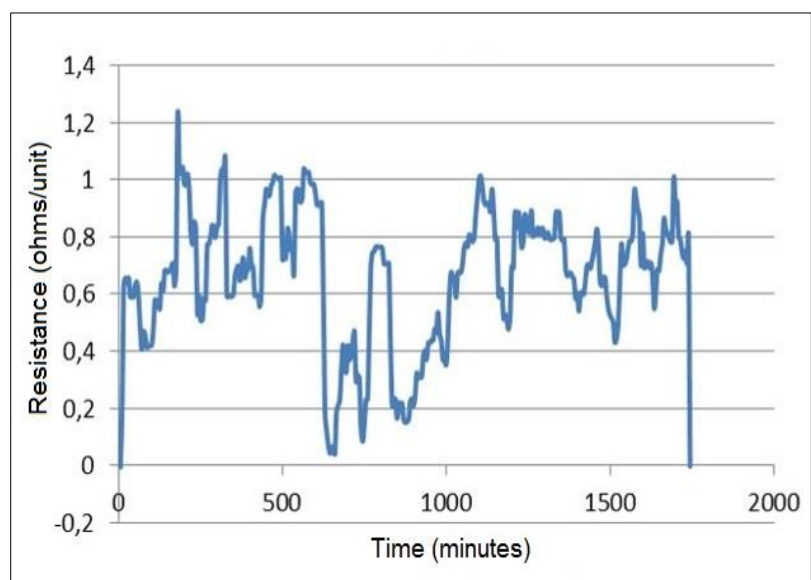

Figure 14 "mr" slope distribution of the A phase.
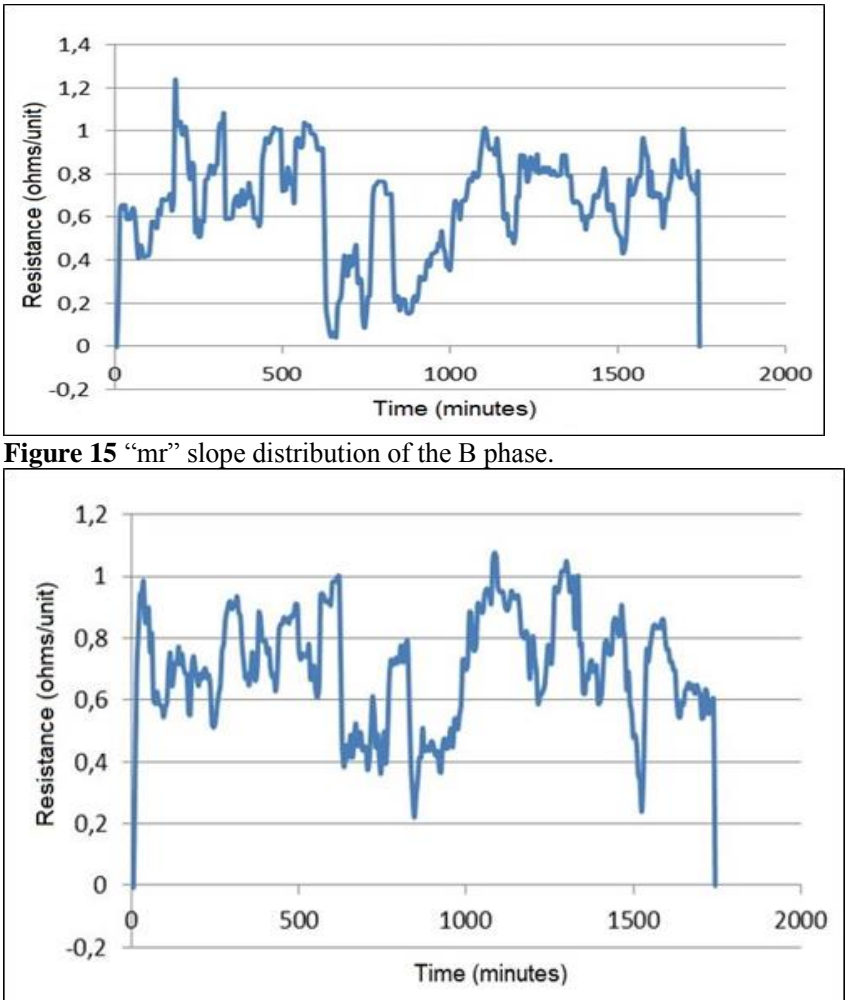

Figure 16 "mr" slope distribution of the $\mathrm{C}$ phase

Also, not having a daily resistance record sheds doubt on whether the phenomenon observed through the graphics with respect to the resistance slope calculated "per unit" is sufficiently consistent to be attributed as characteristic of corrosion damage, given that electric power losses are directly related to conductor resistance, in this case the ACSR cable.

It is fundamental to ensure prolonged exposure times of the samples in the saline fog chamber, not below $720 \mathrm{~h}$, to obtain samples with a higher degree of representativeness of the corrosion phenomenon as a factor of incidence in the electric power losses.

High-resolution scanning electron microscopy (SEM) was used to obtain more detailed information of the layer formed by the corrosion products, given that the pits and fissures on the material are often too small for the BX45 microscope to register.

Given that the tests performed for this research work used high-gauge cables that withstand at least 140 amps, we may implement one of the wires that make up the aluminum cable with steel core to analyze the incidence of the corrosion phenomenon and the electric power losses in areas with lesser surface through where current can cross. Likewise, the nominal current capacity may be delivered to one of the previously mentioned wires to increase its temperature.

Electric power measuring equipment should be used with one more degree of precision than that used in this experiment to lower the margin of error while measuring.

During the 1-h period when drying takes place of the SFC exposure cycle, a daily record of the sample's resistance could be taken to determine its variation and correlate it to the electric power loss phenomenon.

\section{References}

[1] MARTÍN PIRIS, Nuria y BADÍA PÉREZ, José María. Comportamiento en servicio de los materiales metálicos. In: GÜEMES GORDO, Alfredo y MARTÍN PIRIS, Nuria. Ciencia de materiales para ingenieros. Madrid: Pearson, 2012. p. 243-259.

[2] LINARES PÉREZ, Lizeth María. Evaluación de la corrosividad atmosférica y su efecto en los cables de transmisión Eléctrica A $400 \mathrm{Kv}$ de CVG EDELCA. Tesis de Magíster scientiarum en corrosión. Maracaibo: Universidad del Zulia. División de postgrado de la Facultad de Ingeniería, 2007. 134. p.

[3] LAVERDE LAVERDE, Víctor Hugo. Diseño y fabricación de una maquina salina para realizar análisis de corrosión en materiales. Tesis de grado Ingeniero Macarrónico. Bogotá: Universidad Nacional de Colombia. Facultad de Ingeniería. 131. p.

[4] ROMERO ECHETO, Natalie María. Fundamento teórico. In: Evaluación de recubrimientos expuestos a ambientes marinos y costeros marinos. Tesis de Magíster scientiarum en corrosión. Maracaibo: Universidad del Zulia. División de postgrado de la Facultad de Ingeniería, 2004. p. 31-76.

[5] SURAL. Conductores de Aluminio Desnudos. \{On line $\}$. $\{11$ September 2013\}. Available in:

(http://www.sural.com/productos/desnudos/acsr.htm). 


\section{TECCIENCIA}

[6] CORMON. Overhead line corrosion detector. \{On line $\}$. $\{11$

September 2013\}. Available in

(http://www.cormon.com/products/datasheets\%5Cptp002.pdf)

[7] CALITZ, JACQUES. Overhead conductor corrosion study. Tesis de Magíster technologies engineering metallurgical. Tshwane: Tshwane

University of Technology. Faculty of Engineering, 2004. 196. p

[8] GALLEGOS C, Ramiro. El Cobre (Copper). In: Revista

VIRTUALPRO. No 56 (Sept, 2006); p. 5.

[9] CENTRO ESPAÑOL DE INFORMACION DEL COBRE. El Cobre.

\{On line $\}$. \{11 September 2013\}. Available in:

(http://www.copperalliance.es/el-cobre/propiedades).

[10] INGEMECANICA. Propiedades mecánico-químicas del cobre tutorial $\mathrm{N}^{\circ} 112$. \{On line $\}$. \{11 September 2013\}. Available in: (http://ingemecanica.com/tutorialsemanal/tutorialn112.html\#seccion5). [11] REVIE, R. Winston y UHLIG, Herbert H. Definition and importance of corrosion. In: Corrosion and corrosion control. 4ed. New Jersey: John Wiley, 2008. p. 1-6.

[12] ROBERGE, Pierre R. Environments. In: Handbook of Corrosion Engineering. New York: MacGraw-Hill, 2000.p. 58-59.

[13] MARTÍN PIRIS, Nuria y BADÍA PÉREZ, José María.

Comportamiento en servicio de los materiales metálicos. In: GÜEMES GORDO, Alfredo y MARTÍN PIRIS, Nuria. Ciencia de materiales para ingenieros. Madrid: Pearson, 2012. p. 243-259.

[14] MOTT, Robert L. Propiedades de diseño de materiales. In: Resistencia de materiales. 5 ed. México: Pearson, 2009. p. 53-103.

[15] GRAINGER, John J y STEVENSON, William D. Impedancia serie de líneas de transmisión. In: Análisis de sistemas de potencia. México: McGraw-Hill, 1996. p. 131-155.

[16] ROBERGE, Pierre R. Corrosion failures. In: Handbook of Corrosion Engineering. New York: MacGraw-Hill, 2000.p. 332-368.

[17] REVIE, R. Winston and UHLIG, Herbert H. Atmospheric corrosion. In: Corrosion and corrosion control. 4ed. New Jersey: John Wiley, 2008. p. 191-202.

[18] DÍAZ RODRÍGUEZ, Francisco Miguel. Introducción. In: Estudio de la corrosión atmosférica del cinc y el acero galvanizado. Tesis Doctoral en Química. Tenerife: Universidad de La Laguna. Departamento de Química Física, 2001. p. 2-26.

[19] MEDINA Z, José Gregorio y RIVAS B, Fernando Alberto. Análisis de pérdidas técnicas y no técnicas a nivel de $13,8 \mathrm{kV} /(240-120) \mathrm{V}$ en el circuito Coro 1 ubicado en el Estado Falcón (caso: CADAFE). Trabajo de grado Ingeniero Electricista. Valencia: Universidad de Carabobo. Faculta de Ingeniería, 2008. 129 p. \{On line\}. \{11 September 2013\}. Available in: (http://www.riuc.bc.uc.edu.ve/bitstream/123456789/52/1/10891.pdf).

[20] ORDOÑEZ SANCLEMENTE, Jorge P. y NIETO ALVARADO, Leonardo G. Mantenimiento de sistemas eléctricos de distribución. Proyecto de grado Ingeniero Eléctrico. Guayaquil: Universidad Politécnica Salesiana. Facultad de Ingenierías. Carrera de ingeniería eléctrica, 2010. 101 p. \{On line\}. \{Sept. 2013\}. Available in: (http://dspace.ups.edu.ec/bitstream/123456789/2119/15/UPSGT000156.pdf)

[21] HERRERA LEON, Fernando Augusto y FORERO CARO, Luis Miguel. Pérdidas de energía en el sistema de distribución caso Colombia. Informe Ejecutivo. Bogotá, D.C.,: International Copper Association Procobre, 2008. 18 p. \{On line\} \{Aug 2013\} Available in: (https://www.google.com.co/url?sa=t\&rct=j\&q=\&esrc=s\&source=web\&c $\mathrm{d}=1 \&$ ved $=0 \mathrm{CCwQFjAA \& url=http} \% 3 \mathrm{~A} \% 2 \mathrm{~F} \% 2 \mathrm{Fprocobre}$. org $\% 2 \mathrm{Fes} \% 2 \mathrm{~F}$ wp-content $\% 2$ Fplugins $\% 2$ Fdownloadmonitor\%2Fdownload.php\%3Fid\%3D178\&ei=qyY3UvW7Goqu9ATrpID gDg\&usg=AFQjCNEAXpPpQiXcA8LN-
3ZgB6qNJypZ_A\&sig2=DgSplCSLQXQ8dN9SPFYMkg\&bvm=bv.5216 4340,d.eWU)

[22] COLOMBIA. MINISTERIO DE MINAS Y ENERGIA. Resolución 070 (28, mayo, 1998). Por el cual se establece el reglamento de distribución de potencia eléctrica, como parte del reglamento de operación del sistema interconectado nacional. Bogotá, D.C.,: El Ministerio, 1998. $63 \mathrm{p}$.

[23] COLOMBIA. MINISTERIO DE MINAS Y ENERGIA. Resolución 181294 (06, agosto, 2008). Reglamento técnico de instalaciones eléctricas (RETIE). Bogotá, D.C.,: El Ministerio, 2008. 164 p.

[24] MOLINA, Juan David. VILLADA, Fernando. MESA, Noé. La Corrosión Atmosférica En Sistemas De Transporte De Potencia Eléctrica: Modelo De Vida Útil Y Su Remuneración En Colombia. In: Revista Facultad de Ingeniería Universidad de Antioquia. Junio, 2011, no. 59, p. 257-266. \{On line $\}$. \{17 July 2013\}. Available in:

(http://aprendeenlinea.udea.edu.co/revistas/index.php/ingenieria/article/vi ewArticle/13830).

[25] GONZÁLEZ SOUBLETT, Edraz Urvisaely. Estudio de pérdidas de potencia eléctrica en sistemas de distribución usuarios alto consumo ubicados en el casco central de Puerto la Cruz estado Anzoátegui. Trabajo de grado Ingeniero Electricista. Barcelona: Universidad de Oriente núcleo de Anzoátegui. Escuela de ingeniería y Ciencias aplicadas, 2010. 168 p. \{On line $\}$. \{Sep. 2013\}. Available in: (http://ri.biblioteca.udo.edu.ve/bitstream/123456789/3112/1/07TESIS.IE010G33.pdf).

[26] CAÑAR OLMEDO, Santiago Patricio. Cálculo detallado de pérdidas en sistemas eléctricos de distribución aplicado al alimentador Universidad perteneciente a la empresa eléctrica Ambato regional centro norte S.A. Tesis de grado Ingeniero Eléctrico. Quito: Escuela Politécnica Nacional. Facultad de Ingeniería Eléctrica y Electrónica, 2007. 213 p. \{On line\}. \{11 September 2013\}. Available in: (http://bibdigital.epn.edu.ec/bitstream/15000/4217/1/CD-0926.pdf). [27] VÁZQUES GRANDA, Paúl Marcelo. Parametrización, control, determinación y reducción de pérdidas de energía en base a la optimización en el montaje de estaciones de transformación en la provincia de Morona Santiago. Tesis Magíster en sistemas eléctricos de potencia. Cuenca: Universidad de Cuenca. Faculta de Ingeniería, 2013. 107 p. \{On line $\}.\{11$ September 2013\}. Available in: (http://dspace.ucuenca.edu.ec/bitstream/123456789/423/1/Tesis.pdf). [28] CHICO, B., DE LA SOURCE, D. y MORCILLO, M. simulación en laboratorio mediante ensayos de corrosión acelerada de la presencia y contenido en sales solubles en los productos de corrosión atmosférica del acero. In: Revista de metalurgia. 12005 , vol. 41 no. extra, p. 438-442. \{On line $\}$. \{17 July 2013\}. Available in:

(http://revistademetalurgia.revistas.csic.es/index.php/revistademetalurgia/i ssue/view/97). 